\title{
Are Spanish Listed Firms Betting on CSR during the Crisis?
}

\section{Evidence from the Agency Problem}

\author{
María del Mar Miras ${ }^{1}$, Bernabé Escobar ${ }^{1} \&$ Amalia Carrasco ${ }^{1}$ \\ ${ }^{1}$ Department of Accounting and Financial Economics, University of Seville, Seville, Spain \\ Correspondence: María del Mar Miras, Department of Accounting and Financial Economics, University of Seville, \\ Avd. Ramón y Cajal 1, 41018 Seville, Spain. Tel: 34-954-556-048. E-mail: mmiras@us.es
}

Received: March 1, 2014

Accepted: March 18, 2014

Online Published: March 20,2014

doi:10.5430/bmr.v3n1p85

URL: http://dx.doi.org/10.5430/bmr.v3n1p85

\begin{abstract}
Companies have to continue with their businesses in the current uncertain environment triggered by the economic crisis. Since the decrease in the performance of companies is a reality, academicians, managers and entrepreneur are worried about what may be happening with Corporate Social Responsibility.

Because of the strong impact of the crisis on Spain, we are going to study its effect on the CSR behaviour of Spanish companies. Therefore, we analyse whether the performance of the company, as well as some shareholding characteristics, influence CSR before and during the crisis.

The results show that large Spanish companies continue to carry out CSR actions despite the effects of the crisis on their financial health. It seems that shareholders are more influential than managers in these strategic and entrepreneurial decisions. Additionally, the presence of a reference shareholder means that companies are more committed to CSR, although a higher percentage of insider shareholders cause the contrary effect.
\end{abstract}

Keywords: Corporate Social Responsibility, Crisis, Managers, Shareholders

\section{Introduction}

The current financial and economic crisis is a reality as is also the enormous consequences suffered by many companies. This has meant the closing down of several firms, suffering losses, or at best a great reduction in profits. Many companies have therefore been forced to redefine their entrepreneurial strategy and implement austerity plans as the unique alternative in order to be able to survive in this uncertain environment. In this context, both academics and entrepreneurs are asking about how Corporate Social Responsibility (CSR) is going to be influenced by these extraordinary circumstances.

These circumstances may well allow a better and clearer understanding of what the real motivations or interests of carrying out CSR policies are. These have always been questioned by Friedman (1970).

If companies only implement CSR actions seeking legitimacy or direct benefits (a short-term vision), these actions should be drastically affected by the crisis. This agrees with the arguments of the Slack Resources Hypothesis (Waddock \& Graves, 1997) and the Managerial Opportunism Hypothesis (Williamson, 1965). These argue that socially responsible behaviour depends on the availability of resources and on the managers' short-term objectives.

Notwithstanding, if organisations are really engaged with these issues and have really integrated CSR into their business strategy, they could take advantage of the crisis as an opportunity instead of considering it as a threat. The Agency Theory (Ross, 1973) explains that during a crisis period shareholders are more concerned about strategic decisions and pressure managers to continue being engaged with CSR. Therefore, the present crisis may not mean the direct disappearance of CSR actions, although expenditure on them could be reduced.

Despite the relevance of this issue, few researchers have addressed the problem worldwide (Charitoudi,Giannarakis\& Lazarides, 2011; Giannarakis \& Theotokas, 2011), or in specific countries (Schiopoiu, Radu, Craciun, Ionascu \&Lolescu, 2010; Arevalo \& Aravind 2010; Ducassy, 2013). Nevertheless, it is particularly interesting to test this predicament in Spain because (1) it has been one of the European countries most affected by the economic downturn and (2) the real implementation of CSR practices in Spanish companies is so recent - beginning of the 21st centuryand it is considered due to the renewed interest of the European Union (Fernández \& Melé, 2004). 
In this sense, there is not much empirical evidence about how the crisis is affecting Spanish companies' social commitment. There have only been a few studies focusing on the banking sector (Perez \& Rodríguez, 2012; Escobar \& Miras, 2013). Their results cannot necessarily be extrapolated to all Spanish companies. Yet there are reasons why we are so interested in studying the consequences of the financial crisis in Spain on CSR, and why this could be different from in other countries. The evidence comes from the Foretica report (2011), based on a survey of managers or entrepreneurs. This suggests that at least $65 \%$ of Spanish firms maintained or increased their CSR actions during 2010, despite the strong impact of the crisis: almost 130,000 firms closed down between 2008 and 2010.

With the aim of studying what is really happening in Spanish listed firms, we are going to empirically analyse the effect of the crisis on CSR behaviour as well as to study whether the performance of the company influences the CSR before (2005-2007) and during the crisis (2009-2011). Additionally, due to the important role that shareholders have in this strategic decision (Prado, Gallego\& García, 2009), we examine how some characteristics of the shareholding (the existence of a reference shareholder and the percentage of insiders) could affect the CSR behaviour and if these impacts changed during the crisis period (2009-2011).

The result is that large, Spanish companies continue to behave in a socially responsible way despite the crisis and its effects on the financial health of the companies. This means that shareholders are having a greater influence than the managers or entrepreneurs in this particular strategic decision during the crisis period. Facing this new situation, while the presence of a reference shareholder makes companies improve their socially responsible behaviour, a higher percentage of insider shareholders cause the opposite effect because they take on the roles of managers or entrepreneurs.

To achieve the objective proposed, the layout of this article is as follows. Firstly, we discuss CSR and its relationship with the company's Financial Performance (FP) in order to later analyse the effect that the economic crisis could have on CSR, and on the CSR-FP relationship. Then, we look more closely at the sample, the variables and the methodologies used for the analyses. Finally, we report and discuss the results and, at the end, we present the conclusions as well as some limitations of the research.

With respect to the theoretical framework of this study, agency theory and entrepreneurship theory are two approaches with distinct subjects of study in the field of management research. Although both approaches seek to understand and explain the world of organizations, they generally focus on different issues. Nonetheless, in the study presented in this article, entrepreneurship theory and agency theory coincide in two areas. The first is corporate social responsibility (CSR), which, broadly speaking in terms of agency theory, equates to a means of creating social value (Jacobides \& Croson, 2001), while, at the same time, is the result of entrepreneurial activity (Thompson, 2002). Second, these two approaches overlap in the issue of who is responsible for making decisions and the mechanisms behind the decision-making process. This second issue is associated with the nature of the relationships and the balance of power between shareholders and the management—principals and agents-(Fama \& Jensen, 1983a, 1983b). Furthermore, it bears relation to the implementation of policies and strategies in terms of who plays the effective role of positioning the firm in the market-in this case, in relation to CSR-, thereby enabling the discovery and creation of opportunities (Shane \& Venkataraman, 2000; Shane, 2012).

This twofold dimension - agency theory applied to decision making and entrepreneurial activity with regard to the impact of these decisions on policy and strategy - is a recurring theme throughout the article. Although questions of entrepreneurship are merely implicit in this research, the issues under discussion represent an area ripe for expanding the theory of entrepreneurship.

\subsection{Corporate Social Responsibility, Financial Performance and Crisis}

The evolution in the importance and significance of CSR over recent decades is undeniable (Schultz \&Wehmeier, 2010). It has changed from being an irrelevant or fashionable idea to one of the most widely accepted concepts in the business world (Lee, 2008).

Although the idea that firms had some responsibilities to society beyond that of making profits has been around for centuries (Carroll \& Shabana, 2010), it was not until the end of the last century that CSR became a reality in business and one of the determinant factors that has been taken into account in decision-making (Garriga \& Melé, 2004). This is why most international organisations have established guidelines (i.e., Global Reporting Initiative - GRI) and recommendations about how to be a socially and environmentally responsible company. It has also been the cause of a high increment in the number of voluntary social disclosure memories of companies as well as the creation of Sustainability Stock Indexes (Dow Jones Sustainability Index, KLD Domini, FTSE4Good, among others).

Nevertheless, there have still been numerous debates concerning CSR. Some of the most relevant are the lack of 
consensus about the concept (Carroll, 1979; McWilliams, Siegel \&Wright, 2006; Dahlsrud, 2008; Aras \& Crowther, 2009), and discussions about the altruism (Margolis \& Walsh, 2003; Maignan \& Ferrell, 2004; Husted\& De Jesus, 2006) and the voluntariness (Carroll, 1991; Williamson, Lynch-Wood \& Ramsay, 2006) of CSR practices. Within these debates about CSR, it is also important to emphasise the controversy concerning the real reasons why companies carried out CSR actions which could go from a real commitment with society until being motivated by an improvement on the reputation, a need of legitimize or performance rewards (Moon, 2007). It is important since the aim of the CSR practice is going to determine if companies are going to continue with these socially responsible practices taking into account that current economic crisis is seriously affecting Spanish companies' financial outcomes.

In this line, Waddock and Graves (1997) proposed in the Slack Resources Hypothesis that companies will be more or less socially responsible depending on their availability of financial resources. Achieving a better performance will allow great investments to be made in social projects. Consequently, CSR will only be viable in companies with solid and sustainable financial results. So, our first hypothesis is:

\section{$H_{1}$ : The decline in the financial situation of the company negatively affects its CSR commitment.}

According to Fernández (2009), the crisis could be perceived as a threat or an opportunity. On the one hand, she argued that the CSR approach could threaten the firms' survival due mainly to the high cost of its implementation. So it is completely understandable that carrying out a CSR strategy in periods of uncertainty is not expected.

Therefore, with the crisis at its height, companies behave in a more conservative and defensive way (Cheney \& McMillan, 1990). It is therefore usual for companies to have been prompted to move away from socially responsible behaviour in order to be able to satisfy their shareholders' expectations (Giannarakis \& Theotokas, 2011).

Since the current economic crisis arose, business priorities have changed. Liquidity management has become one of the most important aspects. Moreover, all the actions are being carried out in accordance with the financial difficulties (Yelkikalan \& Köse, 2012). Taking into account the uncertain business environment, companies are encouraged to reduce their expenses (Karaibrahimoglu, 2010). This implies revoking their social responsibilities because they generate costs (Orlitzky, Schmidt \&Rynes, 2003). According to Njoroge (2009), the immediate consequences are the delay or cancellation of many CSR initiatives. Yet, Wilson (2008) took an opposite stance to reduce expenses through the decline in the CSR commitment.

However, it is no less true that the number of social needs has been increased during these rough times, as the CSR actions are more necessary than ever (Karaibrahimoglu, 2010). In this way, companies should change or redefine their business objectives in relation to social expectations (Porter \& Kramer, 2002). This is a perfect chance for differentiating them from other firms (Giannarakis \& Theotokas, 2011). In accordance with Arevalo and Aravind's (2010) results, the level of impact of the financial crisis in a company depends mainly on both: the degree of CSR integration in the company -the organisations with a high integration stage and the kind of proactive or reactive CSR strategy that it carries out- as companies which have a proactive approach are more used to coping with new circumstances.

Therefore, CSR could be one of the ways of managing the situation and of helping companies overcome the consequences of the crisis given that society is more sensitive (Fernández, 2009). In addition, this situation is also an opportunity to recover lost trust by the redefining of the relationships between firms and society (Charitoudi et al., 2011).

Most of the empirical studies (Karaibrahimoglu, 2010; Giannarakis \& Theotokas, 2011) that have analysed the effect of the crisis on the CSR worldwide or in specific countries report a significant drop in the level of CSR during the last period studied (2009-2010).

Therefore, since the importance of CSR has been called into question, the current financial situation provides a perfect opportunity to test the real commitment of companies to the CSR approach (Escobar \& Miras, 2013).

The Managerial Opportunism Hypothesis (Williamson, 1965), on the other hand, discussed the purposes of the managers perhaps being different from those of the stakeholders (including shareholders), and the managers' power to affect CSR has been widely recognised (Deckop, Merriman \& Gupta, 2006; Waldman, Siegel \& Javidan, 2006). They are more short-term oriented and seek immediate profitability. In accordance with this, during the crisis managers, worried by the company's financial situation prefer to decrease all the costs whose short-term benefits they are not sure about. This is because their main concern is the company's survival. Hence, the present financial situation would trigger a large diminution of CSR activities or policies. 
In order to avoid these managerial opportunism practices (Miller, 2002), some mechanisms (financial rewards, shares) have been specified in order for the directorsto take into account the interests of the shareholders (Jensen \& Meckling, 1976; Eisenhardt, 1989). According to the Agency Theory (Ross, 1973), solving the conflict between managers and shareholders (Magness, 2008) is quite important in order to come to an agreement about the companies' strategic decisions.

Consequently, shareholders are more involved in companies and pressure managers to continue with CSR policies as they are more focused on the firm's long-term success (Consolandi,Nascenzi \& Jaiswal-Dale, 2008). They take social and environmental aspects into account in their decision-making (Prado et al., 2009). They are therefore more concerned about long-term repercussions and their attitude could be prompted by being aware of the negative consequences of not being socially responsible (Graves \& Waddock, 1994; Margolis \& Walsh, 2003). So, our hypothesis is:

\section{$\mathrm{H}_{2}$ : Despite the crisis, companies increase their CSR commitment.}

However, not all the shareholders have the same view with regard to the importance of CSR (Godos, Fernández \& Cabeza, 2012). If there is a reference shareholder (someone who has the mayority of the voting right, veto power or golden share), he/she has enough power to influence the strategic decisions of the company by appointing directors to the board (Boyd, 1994) and/or shareholder activism (Admati, Pfleiderer \& Zechner, 1994; Lee \& Lounsbury, 2011). Due to their direct link with the companies' actions, they try to establish relationships based on trust with various stakeholders. Therefore, the next hypothesis is:

\section{$H_{3}$ : Companies who have a reference shareholder obtain higher CSR Scores.}

Furthermore, those who are insiders (that is, those who are at the same time involved in the company's management and those who own more than $5 \%$ of the shares) are undoubtledly affiliated to the firm (Anderson, Mansi \& Reeb, 2003), so the repercussions of their social behaviour would be directly related to them as well as the high costs associated with this. The conflict is with those who are involved in the company's management: if they are behaving as managers (Barnea \& Rubin, 2010; Oh, Chang \& Martynov, 2011) or as shareholders. Thus, if they are behaving as managers it is expected that:

$$
H_{4.1 .} . \text { Firms with a higher percentage of insider shareholders get lower CSR scores. }
$$

On the contrary, if they take the shareholders' role:

$$
H_{4.2 .} \text { : Firms with a higher percentage of insider shareholders get higher CSR scores. }
$$

\section{Method}

\subsection{Sample}

The population under study are companies listed in the Spanish Stock Market. They are most of the industries represented in the sample (thirteen). Not all the companies provide CSR data, so the final sample was composed of 38 Spanish firms (Appendix 1) whose data has been provided by ASSET4 (CSR, Economic Score and Shareholder data- Note 1) and DataStream Professional Database (financial data).

\subsection{Variables}

The dependent variable used in the study is the CSR Score. This was made up of the different CSR dimensions identified by KLD and used by several authors (Scholtens \& Zhou, 2008; Kang, Lee \& Huh, 2010, Michelon, Boesso \& Kumar, 2013) -corporate governance, community, diversity, employment quality, environment, human rights, product responsibility- and constructed according to those who give the same importance to all dimensions (Hillman \& Keim, 2001; Waldman et al., 2006; Ioannou \& Serafeim, 2012).

As independent variables, we are going to use a crisis variable (dummy), the Economic Score and as shareholding variables: insiders (percentage of managers and large blockholders), and reference shareholder (if there is a shareholder who has the majority of voting rights, veto power or golden share -dummy).

The crisis variable reflects the situation before the crisis (2005-2007) and during the crisis (2009-2011). We exclude the year 2008 since this is when the financial ratios (ROA and ROE- Note 2) of the companies started to decrease (Figure 1). We choose the Economic Score (Note 3) because this concept reflects a company's overall financial health and its ability to generate long term shareholder value. It helps us to test if the company's financial situation affects its CSR practices. 
Finally, we introduce several control variables, such as the size of the company (Ln Total of Assets), the leverage level, the industry and the previous CSR Score, in accordance with the previous literature (Waddock \& Graves, 1997; Surroca, Tribó \& Waddock,2010; McWilliams \&Siegel, 2001).

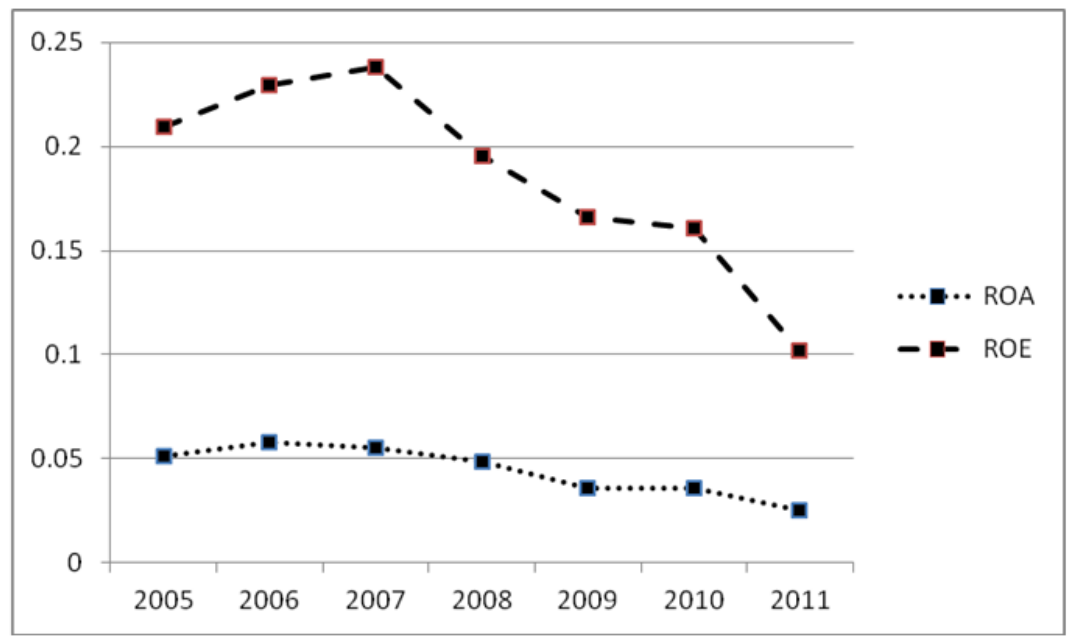

Figure 1. Evolution of the ROA and ROE ratios

\subsection{Statistical technique}

To achieve our aim, we are going to use two different methodologies. Firstly, we are going to predict the score of the different dimensions that we could not take directly from ASSET4 (Community, Diversity, Employment, Product Responsibility and Human Rights) using PLS methodology (Partial Least Squares). This is because we have the scores of different indicators.

One of the main advantages of this technique is that it allows us to predict the dimensions' scores from a list of indicators. It is based on two matters: the indicators and the relationship of the dimensions with the independent variables of the model (Lee, Petter, Fayard \& Robinson, 2011).

Taking the indicators provided by ASSET4 (Appendix 2) into account, firstly, we carry out several tests of collinearity between those included in each dimension to remove those which reveal this problem. That is, those which show FIV $>30$ and two or more correlations over 0.5 . The indicators included at the end are in bold.

Once we have the dimensions' scores, we have constructed the different CSR aggregate measures, and, finally, we estimate several panel data regression models.

\section{Results and Discussion}

As mentioned previously, the aim of the paper is to empirically analyse the influence of the crisis and the financial situation of the company on the CSR responsibilities of Spanish firms. We also study the impact that some characteristics of the shareholding could have on them and if this has changed due to the crisis.

Table 1 presents the correlations between all the main variables included in our analysis. It reveals that CSR is highly correlated with the crisis, economic score and industry variables. However, a non-significant correlation is shown with the shareholding variables (Insiders and Reference Shareholder).

The results for the Crisis and the Financial Health of a company tests are shown in Table 2. Firstly, this shows that the financial health of the companies influences the CSR behaviour proportionally. That is, the better the financial situation of the company, the greater the CSR scores. Taking into account the generalised decreases of the companies' performance during the last year, this would mean that CSR Scores would be decreasing.

Nevertheless, it is necessary to study the effect that the crisis is having on the relationship between CSR and the financial health of the companies. The results show that the crisis has a statistically significant effect on the CSR behaviour of the companies, as Spanish listed firms have been increasing their CSR commitment during this period (2009-2011). This result is surprising considering the negative evidence found worldwide and in other countries (Karaibrahimoglu, 2010; Arevalo \& Aravind, 2010; Giannarakis \& Theotokas, 2011). 
Table 1. Correlation Matrix

\begin{tabular}{|c|c|c|c|c|c|c|c|c|}
\hline & CSR & Crisis & $\begin{array}{l}\text { Economic } \\
\text { Score }\end{array}$ & Insiders & $\begin{array}{l}\text { Reference } \\
\text { Shareholder }\end{array}$ & $\begin{array}{l}\text { Total } \\
\text { Assets }\end{array}$ & Leverage & Industry \\
\hline CSR & 1 & & & & & & & \\
\hline Crisis & $0.246 * *$ & 1 & & & & & & \\
\hline $\begin{array}{l}\text { Economic } \\
\text { Score }\end{array}$ & $0.621^{* *}$ & $0.157^{*}$ & 1 & & & & & \\
\hline Insiders & 0.127 & $0.142 *$ & 0.121 & 1 & & & & \\
\hline $\begin{array}{l}\text { Reference } \\
\text { Shareholder }\end{array}$ & -0.115 & -0.023 & -0.068 & $-0.546^{* *}$ & 1 & & & \\
\hline Total Assets & $0.147^{*}$ & 0.059 & $0.185 * *$ & $0.286^{* *}$ & $-0.130^{*}$ & 1 & & \\
\hline Leverage & $0.168^{*}$ & 0.086 & 0.113 & $0.265^{* *}$ & $-0.131^{*}$ & 0.126 & 1 & \\
\hline Industry & $-0.275^{*} *$ & 0.000 & $-0.218 * *$ & -0.106 & -0.015 & -0.088 & -0.084 & 1 \\
\hline
\end{tabular}

Significant test $* *<0.01 *<0.05$

This fact makes us reconsider the conclusions of the previous analysis. An extra analysis is needed which confirms or rejects them. Therefore, we could see from the last column of Table 2 that CSR is being negatively influenced by the company's financial situation during the crisis. This explains why companies continue to carry out their CSR actions, since in the face of a worse financial situation of the firms (during the crisis) companies get higher CSR scores. A change in the effect of performance on CSR had been identified in France by Ducassy (2013), although this showed an insignificant connection during the crisis.

Table 2. Crisis and Economic Score Regression Models

\begin{tabular}{lllll}
\hline & CSR Score & CSR Score & CSR Score & CSR Score \\
\hline Constant & $0.001(0.03)$ & $-0.002(-0.05)$ & $0.001(0.02)$ & $-0.013(-0.31)$ \\
\hline Eco_Score & & $0.013(1.79) \dagger$ & & \\
\hline Crisis & & $0.016(1.85) \dagger$ & \\
\hline Crisis* Eco_Score & & & $-0.012(-1.79) \dagger$ \\
\hline Size & $-0.001(-0.23)$ & $-0.000(-0.12)$ & $-0.001(-0.38)$ & $0.000(0.09)$ \\
\hline Leverage & $-0.000(-1.03)$ & $-0.000(-1.09)$ & $-0.000(-0.77)$ & $-0.000(-1.02)$ \\
\hline Industry & $0.003(1.26)$ & $0.002(1.18)$ & $0.002(1.07)$ & $0.003(1.44)$ \\
\hline CSR t-1 & $1.005(136.65)^{* * *}$ & $0.994(99.73)^{* * *}$ & $1.000(127.73)^{* * * *}$ & $1.006(136.42)^{* * *}$ \\
\hline \hline Test Wald & $20238.56 * * *$ & $20119.82^{* * *}$ & $20416.54 * * *$ & $20136.11 * * *$ \\
\hline & $* * *<0.005, * *<0.01, *<0.05, \dagger<0.1($ in brackets: z-statistics) &
\end{tabular}

It is true that the strong influence that the previous CSR Score has on the current one is consistent with the idea that being committed to CSR is not exceptional. Rather, it is something that involves planning and it should be in the company's strategy. Once a company is engaged with CSR, society will strongly punish those which decrease their CSR actions (Margolis \& Walsh, 2003). This is especially the case in times of crisis when society is more sensitive than ever. Somehow this requires companies to maintain or increase their commitment to CSR in spite of not enjoying the best financial situation.

Since we have supported our main hypothesis by the important role that the shareholder should play in the companies' strategic decisions during the financial crisis, we are going to see in Table 3 if some characteristics of the shareholding have an impact on the CSR behaviour and whether there are changes in these influences during the 
crisis. We test each characteristic individually (Reference Shareholder and Insiders) on account of the collinearity between the concepts (if the company has a Reference Shareholder, he/she is an insider shareholder too).

Table 3. Shareholders and Crisis Regression Models

\begin{tabular}{lllll}
\hline & CSR Score & CSR Score & CSR Score & CSR Score \\
\hline Constant & $-0.028(-0.26)$ & $-0.016(-0.15)$ & $-0.033(-0.31)$ & $-0.039(-0.37)$ \\
\hline Reference Shareholder & $0.021(2.89)^{* * *}$ & & $-0.011(-1.60)$ \\
\hline Insiders & & & \\
\hline Crisis*Reference Shareholder & & $0.023(3.14)^{* * * *}$ & \\
\hline Crisis* Insiders & & & $-0.013(-1.84) \dagger$ \\
\hline Size & $0.003(0.41)$ & $0.002(0.29)$ & $0.003(0.47)$ & $0.003(0.53)$ \\
\hline Leverage & $0.000(0.10)$ & $0.000(0.52)$ & $0.000(0.62)$ & $0.000(0.78)$ \\
\hline Industry & $-0.003(-0.81)$ & $-0.003(-0.83)$ & $-0.003(-0.91)$ & $-0.003(-0.89)$ \\
\hline CSR t-1 & $0.942(105.53)^{* * *}$ & $0.942(105.90)^{* * *}$ & $0.942(103.30)^{* * *}$ & $0.939(104.51)^{* * *}$ \\
\hline \hline Test Wald & $13119.90 * * *$ & $13202.72 * * *$ & $12798.24 * * *$ & $12839.97 * * *$
\end{tabular}

From the results, we can say that the existence of a reference shareholder in whom the power of the company is concentrated makes that the CSR score continues to grow regardless of there being an economic crisis.

Notwithstanding, organisations with a high percentage of insider shareholders, show a negative effect on the CSR actions during the crisis that is not revealed in the previous period (a non-significant relationship). This explains that in companies whose shareholders are involved in its management, the agency problem becomes imperceptible during the crisis -not many differences between the ownership and the management- with them behaving more as managers than as shareholders. This is consistent with the evidence found by Barnea \& Rubin (2010) and Oh et al. (2011).

\section{Conclusions}

The aim of our research involves analysing whether the CSR behaviour of Spanish companies has been influenced by the present financial crisis. In addition, it tests if the CSR behaviours have been affected equally by the performance, as well as by some kind of shareholders, before the crisis (2005-2007) and during the crisis (2009-2011).

Spanish listed firms have adopted a long-term approach to manage CSR. Hence, they are trying to continue carrying out CSR policies, although in most the cases this involves making significant changes in their CSR strategy. In this regard, it should be noted that these increases in the scores do not necessarily mean that the costs of CSR in companies have been enhanced, because this would not be consistent with the economic situation of the country and businesses.

These results agree with the opinions revealed by directors about Spanish companies (Forética, 2011), but otherwise they are surprising because in no other empirical work had CSR increases during the crisis (2009-2011) been obtained. This reinforces the idea that large Spanish companies continue taking into consideration the CSR approach during the crisis. They try to behave in a socially responsible way.

Additionally, the financial situation of the company influences its CSR behaviour, even though its impact changes due to the crisis. During the crisis, the effect that the financial health of the companies has on CSR is negative. That is, contrary to a worsening of the company's financial situation, the CSR scores have improved.

Thus, in the light of the results, we can say that they show that shareholders are more influenced than managers by this particular strategic decision of the companies (mainly by the reference shareholder) during the crisis.

The conclusions drawn allow us to rethink the real reason for CSR. This has long been linked to a fashion and the financial returns in times of economic boom. 
Regarding the paper's limitations, the conclusions cannot be extrapolated to Small and Medium-sized companies because the sample of our study is composed of Spanish listed companies. Another important caveat is that CSR is measured by a score made up of seven dimensions, and those companies which are more focused on one or two dimensions get a lower CSR score.

\section{Acknowledgements}

We would like to thank the editor and reviewers for the suggestions made which have improved the quality of the manuscript.

\section{References}

Admati, A.R., Pfleiderer, P., \& Zechner, J. (1994). Large shareholder activism, risk sharing, and financial market equilibrium. The Journal of Political Economy, 102, 1097-1130. http://dx.doi.org/10.1086/261965

Anderson, R.C., Mansi, S.A., \& Reeb, D.M. (2003). Founding family ownership and the agency cost of debt. Journal of Financial Economics, 68, 263-285. http://dx.doi.org/10.1016/S0304-405X(03)00067-9

Aras, G., \& Crowther, D. (2009). Corporate Sustainability Reporting: A Study in Disingenuity?. Journal of Business Ethics, 87, 279-288. http://dx.doi.org/10.1007/s10551-008-9806-0

Arevalo, J.A., \& Aravind, D. (2010). The impact of the crisis on corporate responsibility: the case of UN global compact participants in the USA. Corporate Governance, 10(4), 406-420. http://dx.doi.org/10.1108/14720701011069641

Barnea, A., \& Rubin, A. (2010). Corporate social responsibility as a conflict between shareholders. Journal of Business Ethics, 97, 71-86. http://dx.doi.org/10.1007/s10551-010-0496-z

Boyd, B.K. (1994). Board control and CEO compensation. Strategic Management Journal, 15, 335-344. http://dx.doi.org/10.1002/smj.4250150502

Carroll, A.B. (1979). A Three-Dimensional Conceptual Model of Corporate Performance. Academy of Management Review, 4, 497-505. http://dx.doi.org/10.5465/AMR.1979.4498296

Carroll, A. (1991). The pyramid of corporate social responsibility: toward the moral management of organizational stakeholders. Business Horizons, 4, 39-48. http://dx.doi.org/10.1016/0007-6813(91)90005-G

Carroll, A.B., \& Shabana, K.M. (2010). The Business Case for Corporate Social Responsibility: A Review of Concepts, Research and Practice. International Journal of Management Reviews, 12, 85-105. http://dx.doi.org/10.1111/j.1468-2370.2009.00275.x

Charitoudi, G., Giannarakis, G., \& Lazarides, T.G. (2011). Corporate Social Responsibility Performance in Periods of Financial Crisis. European Journal of Scientific Research, 63, 447-455.

Cheney, G., \& McMillan, J.J. (1990). Organizational rhetoric and the practice of criticism. Journal of Applied Communication Research, 18(2), 93-114. http://dx.doi.org/10.1080/00909889009360318

Consolandi, S.C., Nascenzi, S.P., \& Jaiswal-Dale, S.A. (2008). Ownership concentration and corporate social performance: An empirical evidence for European firms. Corporate Responsibility Research Conference, Belfast (2008).

Dahlsrud, A. (2008). How corporate social responsibility is defined: an analysis of 37 definitions. Corporate Social Responsibility and Environmental Management, 15, 1-13. http://dx.doi.org/10.1002/csr.132

Deckop, J.R., Merriman, K.K., \& Gupta, S. (2006). The effects of CEO pay structure on corporate social performance. Journal of Management, 32, 329-342. http://dx.doi.org/10.1177/0149206305280113

Ducassy, I. (2013). Does Corporate Social Responsibility Pay Off in Times of Crisis? An Alternate Perspective on the Relationship between Financial and Corporate Social Performance. Corporate Social Responsibility and Environmental Management, 20, 157-167. http://dx.doi.org/10.1002/csr.1282

Eisenhardt, K.M. (1989). Agency Theory: An Assessment and Review. Academy of Management Review, 14, 57-74. http://dx.doi.org/10.5465/AMR.1989.4279003

Escobar, B., \& Miras, M.M. (2013). Spanish Savings Banks' Social Commitment: just pretty words?. Social Responsibility Journal, 9, 427- 440. http://dx.doi.org/10.1108/SRJ-09-2011-0084

Fama, E.F. (1983a). Separation of Ownership and Control. Journal of Law and Economics, 26, 301-325. http://dx.doi.org/10.1086/467037 
Fama, E.F. (1983b). Agency Problems and Residual Claims. Journal of Law and Economics, 26, 327-349. http://dx.doi.org/10.1086/467038

Fernandez, B. (2009). Crisis and Corporate Social Responsibility: Threat or Opportunity?. International Journal of Economic Sciences and Applied Research, 2, 36-50.

Fernández, J.L., \& Melé, D. (2004). Spain: From a paternalistic past to sustainable companies. In: Corporate social responsibility across Europe. Discovering national perspectives of corporate citizenship (Eds. André Habish, Jan Jonker, Martina Wegner, René Schmidpeter), 289 - 302. Berlin; New York: Springer.

Friedman, M. (1970). The Social Responsibility of Business is to Increase Its Profits. New York Times, 13 September 1970, 122-126.

Forética. 2011. Evolución de la Responsabilidad Social de las empresas en España. http://www.foretica.org/biblioteca/informes-foretica/cat_view/107-informes-foretica?view=docman\&lang=es

Garriga, E., \& Melé, D. (2004). Corporate Social Responsibility Theories: Mapping the Territory. Journal of Business Ethics, 53, 51-71. http://dx.doi.org/10.1023/B:BUSI.0000039399.90587.34

Giannarakis, G., \& Theotokas, I. (2011). The Effect of Financial Crisis in Corporate Social Responsibility Performance. International Journal of Marketing Studies, 3, 2-10.

Godos, J.L., Fernández, R., \& Cabeza, L. (2012). Propiedad y control en la puesta en práctica de la RSC. Cuadernos de Economía y Dirección de la Empresa, 15, 1-11. http://dx.doi.org/10.1016/j.cede.2011.06.002

Graves, S.B., \& Waddock, S.A. (1994). Institutional owners and corporate social performance. Academy of Management Journal, 37, 1034-1046.http://dx.doi.org/10.2307/256611

Hillman, A.J., \& Keim, G.D. (2001). Shareholder value, stakeholder management, and social issues: what's the bottom line? $\quad$ Strategic Management Journal, 22 22 http://dx.doi.org/10.1002/1097-0266(200101)22:2<125::AID-SMJ150>3.0.CO;2-H

Husted, B.W., \& De Jesús, J. (2006). Taking Friedman seriously: maximizing profits and social performance. Journal of Management Studies, 43, 75-91. http://dx.doi.org/10.1111/j.1467-6486.2006.00583.x

Ioannou, I., \& Serafeim, G. (2012). What drives corporate social performance? The role of nation-level institutions. Journal of International Business Studies, 43, 834-864. http://dx.doi.org/10.1057/jibs.2012.26

Jacobides, M.G., \& Croson, D.C. (2001). Information policy: shaping the value of agency relations. Academy Management Journal, 26(2), 202-223. http://dx.doi.org/10.5465/AMR.2001.4378014

Jensen, M.C., \& Meckling, H.W. (1976). Theory of the firm: managerial behavior, agency costs, and ownership structure. Journal of Financial Economics, 3, 305-360. http://dx.doi.org/10.1016/0304-405X(76)90026-X

Kang, K.H., Lee, S., \& Huh, C. (2010). Impacts of positive and negative corporate social responsibility activities on company performance in the hospitality industry. International Journal of Hospitality Management, 29, 72-82. http://dx.doi.org/10.1016/j.ijhm.2009.05.006

Karaibrahimoglu, Y.Z. (2010). Corporate social responsibility in times of financial Crisis. African Journal of Business Management, 4, 382-389.

Lee, M.D.P. (2008). A review of the theories of corporate social responsibility: Its evolutionary path and the road ahead. International Journal of Management Reviews, 10, 53-73. http://dx.doi.org/10.1111/j.1468-2370.2007.00226.x

Lee, M.D.P., \& Lounsbury, M. (2011). Domesticating radical rant and rage: An exploration of the consequences of environmental shareholder resolutions on corporate environmental performance. Business \& Society, 50, 155-188. http://dx.doi.org/10.1177/0007650310394640

Lee, L., Petter, S., Fayard, D., \& Robinson, S. (2011). On the use of partial least squares path modeling in accounting research. International Journal of Accounting Information Systems, 12, 305-328. http://dx.doi.org/10.1016/j.accinf.2011.05.002

Magness, V. (2008). Who are the stakeholders now? An empirical examination of the Mitchell, Agle, and Wood theory of stakeholder salience. Journal of Business Ethics, 83(2), 177-192. http://dx.doi.org/10.1007/s10551-007-9610-2

Maignan, I., Ferrell, O.C. (2004). Corporate Social Responsibility and Marketing: An Integrative Framework. 
Journal of the Academy of Marketing Science, 32, 3-19. http://dx.doi.org/10.1177/0092070303258971

Margolis, J.D., \& Walsh, J.P. (2003). Misery Loves Companies: Rethinking Social Initiatives by Business. Administrative Science Quarterly, 48, 268-305. http://dx.doi.org/10.2307/3556659

McWilliams, A., Siegel, D. (2001). Corporate Social Responsibility: A Theory of the Firm Perspective. Academy of Management Review, 26, 117-127. http://dx.doi.org/10.5465/AMR.2001.4011987

McWilliams, A., Siegel, D.S., \& Wright, P.M. (2006). Corporate Social Responsibility: Strategic Implications. Journal of Management Studies, 43, 1-18. http://dx.doi.org/10.1111/j.1467-6486.2006.00580.x

Michelon, G., Boesso, G., \& Kumar, K. (2013). Examining the Link between Strategic Corporate Social Responsibility and Company Performance: An Analysis of the Best Corporate Citizens. Corporate Social Responsibility and Environmental Management, 20, 81-94. http://dx.doi.org/10.1002/csr.1278

Miller, J.L. (2002). The Board as a Monitor of Organizational Activity: The Applicability of Agency Theory to Nonprofit Boards. Nonprofit Management and Leadership, 12, 429-450. http://dx.doi.org/10.1002/nml.12407

Moon, J. (2007). The contribution of corporate social responsibility to sustainable development. Sustainable Development, 15, 296-306. http://dx.doi.org/ 10.1002/sd.346. http://dx.doi.org/10.1002/sd.346

Njoroge, J. (2009). Effects of the global financial crisis on corporate social responsibility in multinational companies in Kenya. Retrieved 30 December, 2009, from www.covalence.ch/docs/Kenya-Crisis.pdf.

Oh, W.Y., Chang, Y.K., \& Martynov, A. (2011). The effect of ownership structure on corporate social responsibility: Empirical evidence from Korea. Journal of Business Ethics, 104, 283-297. http://dx.doi.org/10.1007/s10551-011-0912-z

Orlitzky, M., Schmidt, F.L., \& Rynes, S.L. (2003). Corporate Social and Financial Performance: A Meta-Analysis. Organization Studies, 24, 403-441. http://dx.doi.org/10.1177/0170840603024003910

Pérez, A., \& Rodríguez, I. (2012). La imagen de Responsabilidad Social Corporativa en un contexto de crisis económica: El caso del sector financiero en España. Universia Business Review, 33, 14-29.

Prado, J.M., Gallego, I., \& García, I.M. (2009). Stakeholder engagement and corporate social responsibility reporting: the ownership structure effect. Corporate Social Responsibility and Environmental Management, 16, 94-107. http://dx.doi.org/10.1002/csr.189

Porter, M.E., \& Kramer, M.R. (2002). The Competitive Advantage of Corporate Philanthropy. Harvard Business Review, December, 57-68.

Ross, S.A. (1973). The Economic Theory of Agency: The Principal's Problem. The American Economic Review, 63, 134-139.

Schiopoiu, A., Radu, C., Craciun, L., Ionascu, C., \& Lolescu, R. (2010). The relationship between financial crisis, corruption and Corporate Social Responsibility in Romania. Management \& Marketing, 8, 65-72.

Scholtens, B., \& Zhou, Y. (2008). Stakeholder relations and financial performance. Sustainable Development, 16, 213-232. http://dx.doi.org/10.1002/sd.364

Schultz, F., \& Wehmeier, S. (2010). Institutionalization of corporate social responsibility within corporate communications: Combining institutional, sensemaking and communication perspectives. Corporate Communications: An International Journal, 15, 9-29. http://dx.doi.org/10.1108/13563281011016813

Shane, S. (2012). Reflections on the 2010 AMR Decade Award: Delivering on the Promise of Entrepreneurship as a Field of Research. Academy Management Review, 37, 10-20. http://dx.doi.org/10.5465/amr.2011.0078

Shane, S., \& Venkataraman, S. (2000). The promise of entrepreneurship as a field of research. Academy of Management Review, 25: 217-226.

Surroca, J., Tribó, J., \& Waddock, S. (2010). Corporate Responsibility and Financial Performance: the role of Intangible Resources. Strategic Management Journal, 31, 463-490. http://dx.doi.org/10.1002/smj.820

Thompson, J. L. (2002). The world of the social entrepreneur. International Journal of Public Sector Management, 15: 412-431. http://dx.doi.org/10.1108/09513550210435746

Waddock, S.A., \& Graves, S.B. (1997). Corporate Social Performance-Financial Performance Link. Strategic Management

Journal, $18(4)$,

303-319. http://dx.doi.org/10.1002/(SICI)1097-0266(199704)18:4<303::AID-SMJ869>3.0.CO;2-G 
Waldman, D.A., Siegel, D.S., \& Javidan, M. (2006). Components of CEO Transformational Leadership and Corporate Social Responsibility. Journal of Management Studies, 43, 1703-1725. http://dx.doi.org/10.1111/j.1467-6486.2006.00642.x

Williamson, D., Lynch-Wood, G., \& Ramsay, J. (2006). Drivers of environmental behaviour in manufacturing SMEs and the implications for CSR. Journal of Business Ethics, 67, 317-330. http://dx.doi.org/10.1007/s10551-006-9187-1

Williamson, O.E. (1965). The Economics of Discretionary Behavior: Managerial Objectives in a Theory of the Firm. Chicago: Markham.

Wilson, A. (2008). Deepening financial crisis should not derail corporate social responsibility. Retrieved September 2012 , http://www.kyivpost.com/content/business/deepening-financial-crisis-should-not-derail-corpo-30379.html.

Yelkikalan, N., \& Köse, C. (2012). The Effects of the Financial Crisis on Corporate Social Responsibility. International Journal of Business and Social Science, 3, 292-300.

\section{Notes}

Note 1. This data base has already been used for this purpose by Ioannou and Serafeim (2012), due to its being much employed by investors to build their sustainability reports. It provides a collection of indicators (valued from 0 to 100) organised into four pillars: Social Scores, Environmental Scores, Corporate Governance Scores and, finally, Economic Scores.

Note 2. ROA: Net Income/Total Assets. ROE: Net Income/Total Equity.

Note 3. The Economic Score measures a company's capacity to generate sustainable growth and a high return on investment through the efficient use of all its resources. This Economic Score is different to the other financial measures because it includes some intangible measures of client loyalty, performance and shareholder loyalty apart from taking into account traditional financial measures. 